\title{
Abstract \\ The Impact of Si Fertilization on Healthy Attributes and Yield of Grains of Wheat Plants Grown under P Deficiency ${ }^{\dagger}$
}

\author{
Isis Vega ${ }^{1,2, *}$, Sofia Pontigo ${ }^{1,2}$ and Paula Cartes ${ }^{1,2, *}$ \\ 1 Center of Plant, Soil Interaction and Natural Resources Biotechnology, Scientific and Technological \\ Boiresources Nucleus, Universidad La Frontera, P.O. Box 54-D, Temuco 4780000, Chile; \\ sofia.pontigo@ufrontera.cl \\ 2 Department of Chemical Science and Natural Resources, Universidad La Frontera, P.O. Box 54-D, \\ Temuco 4780000, Chile \\ * Correspondence: i.vega01@ufromail.cl (I.V.); paula.cartes@ufrontera.cl (P.C.) \\ + Presented at the 1st International Electronic Conference on Agronomy, 3-17 May 2021. Available online: \\ https://iecag2021.sciforum.net/.
}

Citation: Vega, I.; Pontigo, S.; Cartes, P. The Impact of Si Fertilization on Healthy Attributes and Yield of Grains of Wheat Plants Grown under P Deficiency. Biol. Life Sci. Forum 2021, 3, 39. https://doi.org/ 10.3390/IECAG2021-09701

Academic Editor: Peter Langridge

Published: 1 May 2021

Publisher's Note: MDPI stays neutral with regard to jurisdictional claims in published maps and institutional affiliations.

Copyright: (C) 2021 by the authors. Licensee MDPI, Basel, Switzerland. This article is an open access article distributed under the terms and conditions of the Creative Commons Attribution (CC BY) license (https:// creativecommons.org/licenses/by/ $4.0 /)$.
Abstract: Phosphorus (P) deficiency is one of the major limiting factors of wheat production worldwide. Although silicon $(\mathrm{Si})$ is known to improve plant growth under low phosphorus $(\mathrm{P})$ conditions, the impact of Si supply on the nutritional quality of wheat grains at field conditions remains unclear. This study aimed to investigate the impact of Si fertilization on the healthy attributes and yield of grains of wheat plants grown under a P deficiency. A field experiment on an Andisol with low available P content never amended with Si fertilizer was conducted. Two wheat cultivars with contrasting tolerance to P deficiency (cv. Púrpura, sensitive to P deficiency; and cv. Fritz, tolerant to P deficiency) were used during two growing seasons. Three $\mathrm{P}$ doses $\left(0,200\right.$, and $400 \mathrm{mg} \mathrm{P} \mathrm{kg}{ }^{-1}$ soil; as triple superphosphate) were applied in combination with three Si doses $\left(0,250\right.$, and $500 \mathrm{mg} \mathrm{Si} \mathrm{kg}^{-1}$ soil; as magnesium silicate). At the mature grain stage, $\mathrm{Si}$ and $\mathrm{P}$ concentration, total phenols, phenolic acids, radical scavenging activity, and yield components were evaluated. At both growing seasons, Si supply enhanced the grain $\mathrm{P}$ concentration of cv. Púrpura grown in the absence of $\mathrm{P}$, whereas grain $\mathrm{Si}$ concentration increased in both cultivars along the gradient of P supply. Interestingly, increasing $\mathrm{Si}$ doses augmented the phenol concentration and antioxidant capacity in grains of cv. Púrpura grown without $\mathrm{P}$ in both growing seasons. In contrast, Si decreased grain phenol concentration of cv. Fritz under P deficiency. A slight increment of phenolic acids induced by $250 \mathrm{mg} \mathrm{kg}^{-1} \mathrm{Si}$ was also detected in grains of both wheat cultivars grown without P. A positive effect of Si fertilization on the grain yield of both wheat cultivars was also found. In the first growing season, Si added to P deficient plants increased grain yield by about $23 \%$ and $47 \%$ in cv. Púrpura and cv. Fritz, respectively. A significant increase in grain yield was also observed in both wheat cultivars in the second year of the field assay. Taken together, our finding showed that Si fertilization improved the P concentration, phenols production, antioxidant capacity and yield of wheat grains under low $\mathrm{P}$ conditions. In this way, Si fertilization could be used as a potential strategy to improve crop production in soils with low P availability. Acknowledgments. FONDECYT Regular Project N 1201257.

Keywords: silicon; P deficiency; wheat; grains; phenols

Supplementary Materials: The poster presentation is available online at https:/ /www.mdpi.com/ article/10.3390/IECAG2021-09701/s1.

Funding: This research was funded by FONDECYT Regular Project $N^{\circ} 1201257$.

Institutional Review Board Statement: Not applicable.

Informed Consent Statement: Not applicable.

Conflicts of Interest: The authors declare no conflict of interest. 